\title{
Formulation of Law Education by Higher Education for Local Bestuurs Orgaan for The Embodiment of Nationalism Based Human and Law Development
}

\author{
$1^{\text {st }}$ Mas Anienda T.F. \\ Faculty of Law \\ UPN "Veteran" of East java \\ Surabaya, Indonesia \\ masanienda.ih@upnjatim.ac.id
}

\author{
$2^{\text {nd }}$ Anajeng Esri Edhi Mahanani \\ Faculty of Law \\ UPN "Veteran" of East java \\ Surabaya, Indonesia \\ anajengmahanani.ih@upnjatim.ac.id
}

\author{
$3^{\text {rd }}$ Novia Ayu Permatasari \\ Faculty of Law \\ UPN "Veteran" of East java \\ Surabaya, Indonesia \\ noviaayu.ih@upnjatim.ac.id
}

\begin{abstract}
The research discuses about the problem of law education urgency by higher education for localbestuurs organ. The research describes about the local government condition in its relation with the legal cases and the administrative violation by the local government. The research is normative, with qualitative method and literature study, then synergized with law enforcement principle and nationalism based human resources development. The results showed that the many criminal acts by local government in this case relate with the governmental administration, that is corruption, or administrative violation that relates with public services, the occurrence because of lack synergy between legal substain, legal structure and legal culture at local bestuurs organ. To answer the problems, it need a law education formulation that can be implemented by the higher education especially faculty of law, because the higher education should contribute to societies, through education for local government. Formulation of law education can be implemented through education and training through cooperation with the Local Staffing Agency. The procedure can be done through employee cadre formation in each Local Staffing Agency, for then can be developed during education and training for State Civil Apparatus in each area. It should be entered the nationalistic and nationalism education, and law education that is not only technical in the education and training.
\end{abstract}

Keywords: law education, higher education, nationalism

\section{INTRODUCTION}

Legal cases become ghosts for the local officials (local bestuursorgaan)then produce the societal trust degradation to the local bestuursorgaan. Based on KPK statistical data at website Anti Corruption Clearing Houseabout criminal acts of corruption based on the post profession up to 2016 it is found 222 state officials do corruption,[1]while based on the Internal Affair Minister Record,[2] until 2007 found, 343 regents/mayors and 18 governors did corruptions. Data of Indonesia Corruption Watch (ICW)in 2017,[3]showed at least 58 regions (provinces, regencies/cities) which were indicated as political dynasty. The last, data 2018 from January to July 2018, found 19 local head corrupted.[4]Even the newest, news about City Assembly of Malang, 41 members from 45 assembly members arrested,[5]very shaming for the Malang city government, where the City Assembly by the local government act entered as one of local government administration elements.

Beside, the local government administration also conducts maladministration. It is found in data at the website of Ombudsman of RI,[6]in 2017 the institution received report from societies for the maladministrative in the public services in local government of 3.445 report through Ombudsman RI and the Report Verification Receiving Team.

The problems of course will produce anxieties become maintained in the local societies, if not solved. Solution of law education and nationalism planting for localbestuurs organcan be used as the best solution. The intended education is for the embodiment of human development which is aware about law, obey law, and has nationalism for the state and the societies.

Higher education as the container for the character formation and produce nation change agents, has moral duty to give education includes to the localbestuursorgaan. Academics at the higher education not only has task to teach, but also to educate as one of Three Obligations of higher education, that is education and teaching, it is expected from the investigation group or the research group able to widen the network of higher education with local government with goal to give law education for local bestuursorgaan.

Higher education should give contribution to the societies, and through network development to give law education to local bestuursorgaan as one of embodiment. The relation with the law education, then the assignment especially at the faculty of law in the higher education can take role to solve the task to give law education for the local bestuursorgaan. The final goals here to solve bureaucratic problems, embody good governance and build character and mentality improvement of local bestuursorgaan.Then it should be known the factors for the criminal acts and administrative violation by local bestuursorgan, so can be formulated the ideal law education for the local bestuursorgaan?

\section{RESEARCH METHODS}

This paper is a normative legal research conducted using library research. Library research is conducted to obtain secondary data with material or material in the form of books, articles, research results, and legislation, as well as expert opinions relating to the formulation of law education for local bestuurs orgaan. This paper research is carried out through the statutory approach, case approach, and conceptual approach.[7] The data collected in this study were then analyzedqualitative, namely by analyzing which is 
basically returned to three aspects, namely classifying, comparing, and linking.[8] Against the data that has been collected from the library research, it will be analyzed qualitatively to answer the problems raised.

\section{RESULTS AND DISCUSSION}

\section{A. Local BestuursOrgaancondition today relate to the criminal acts of corruption and mal administration in local government.}

Local bestuursorgaantoday become the supervision focus of the societies, recall to this era in Indonesia post reformation, the local government has wide authorities in managing its household or to fulfill the societies need in the Unitary State of The Republic of Indonesia. Compared to the pre reformation, or called as New Order, almost 32 years the New Order government run in authoritarian way and centralistic,[7]in this case the power centered at the bureaucratic ruler of government. Developmental and governmental control at the central hand.[8]

The existence of central governments in this case filled by localbestuursorgan become the reference for the reform success, that is to accelerate and bring nearer the public services to the local societies. It is along with the local autonomy principle to the autonomous local government.

According to Article 1 Number 6 Law 23 Year 2014 about Local Government as changed by Law No 9 Year 2015, "local autonomy is right, authority, and responsibilities of of autonomous area to regulate and manage themselves their governmental affairs and the societal interest in the system of The Unitary State of The Republic of Indonesia".

The definition showed the presence of autonomous principle of local government. H.M. Busrizaltialso explains in his book, that:

Discusses about local autonomy in Indonesia relate with the concept and theory of local government and how the application in the local government administration in Indonesia. Local governmentis part of state then local government concept can not be separated from the sovereignty concept in the unitary and federal system and centralization, decentralization, and assistance task.[9]

The concept actually beside encourage the local autonomy also in taking policy, the governmental administrator apparatus look at the condition and needs of the society. It is suitable with opinion of H.A.W.Widjajain his book entitled "Local Autonomy and Autonomous Area", as follows:

Core of local autonomy concept is maximizing the results that will be achieved and also avoid the complexity and the inhibiting things for the local autonomy. So, the societal requirement can be embodied in reality by implementing the wide local autonomy and the survival of public services is not ignored so maintains the fiscal continuity nationally.[10]

Recall to the consideration that relate with the local autonomy above, then the position of local bestuursorgaanhas important role. In this case, localbestuursorgan is expected in implementing the local government not producing disappointment to the local societies, beside that also based on the principles of good governance based on law. The final goal is to create good governanceto support good government yang based on law in legal state.

Law No. 5 Year 2014 about State Civil Apparatus also explains that in effort to reach national goals as given in $4^{\text {th }}$ paragraph of Constitution Preamble of Unitary State of The Republic of Indonesia Year 1945 (UUDNRI Year 1945) that is to protect all Indonesia people, improve general welfare, educating the national life, and participating in the world order based on independence, eternal peace, and social justice, it needs professional, free from corruption, collusion, and nepotism apparatus, able to implement public services for the societies an able to implement the role as the adhesive of unity of the state based on Constitution UUD 1945 .

Das sollen of local government administration by local bestuursorgaan, of course also collide with das sein. Actually not all local bestuursorgaanunderstand the governmental administration based on good governance and based on law. What thing that become hypothesis is based on the many legal cases and administrative violation often occurred in the local government institutions.

Legal case become the societal highlight relate with the government in the governmental administration is the criminal acts of corruption. Many criminal acts of corruption done by local government can be seen from the statistic below.

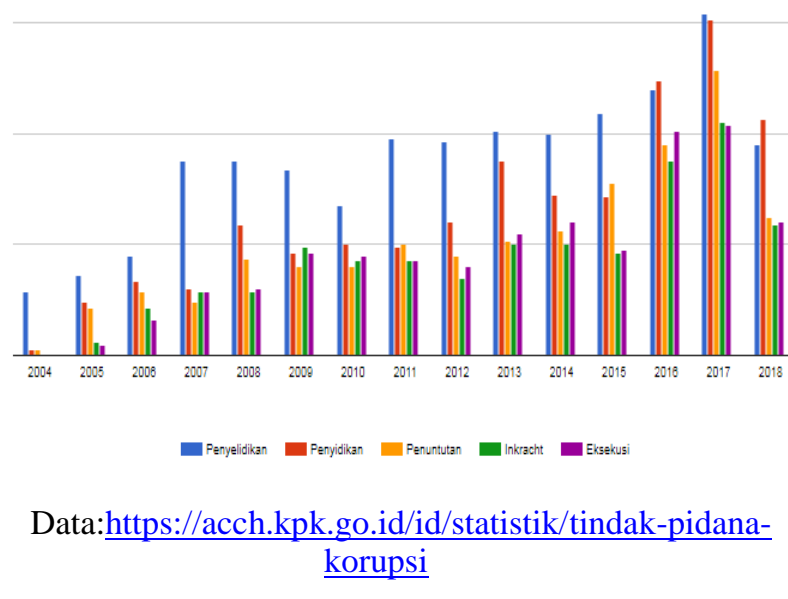

Based on the data, it is knokwn that average corruption by government increase. Data 2018do not reach final, caused no budget closing yet. The data if investigated further based on institution often do corruption, can be seen further through the statistic below: 


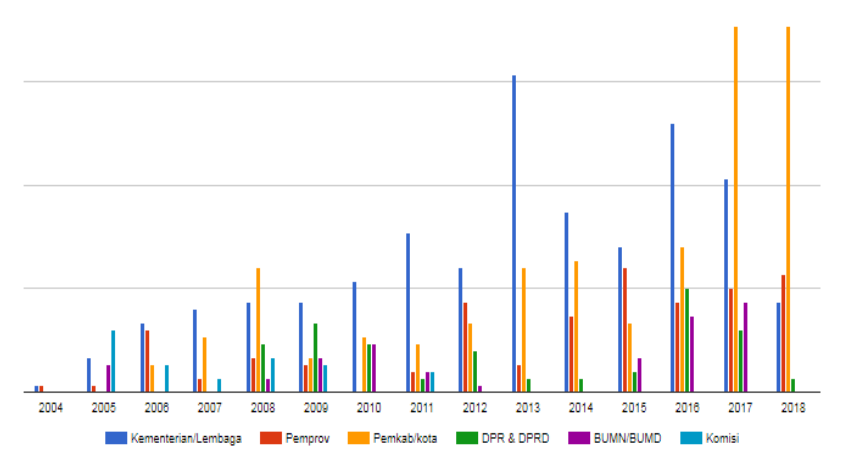

Data: https://acch.kpk.go.id/id/statistik/tindakpidana-korupsi

Data above shows the high corruption done by the regency/city government. Even if added with data of Local Assembly as one element of the local government administrators. Criminal act of corruption still become ghost in the local government administration.

Then if it is related to the administrative violation. The administrative violation, by localbestuursorgaan, in this case relate with the public service administration that is lack optimum. According to Law No25 Year 2009 about Public servicesin Article 1 stated:

"Public service is activity or series activities in order to fulfill the services fulfillment suitable with the law and regulation for each citizen and population for goods and services, and/ or administrative services given by public administrator"

Based on the definition above can be understood that the public servicesfunction is very dominating in case societal satisfaction toward the local government or local bestuursorgaan. Relate with the matters, then the administrative law understanding especially that relates with the good governmental principle, state administrative dispute, up to the administrative justice is needed by local bestuursorgaan. It is a preventive effort to prevent administrative law violation in local area.

In governmental and statehood implementation, the public servicesfunction has been done, but in reality, the public servicesnot show significant change yet. The many complaints and accusation showed that thepublic servicesquality is very low. Denunciation and complaint about complicated services procedures, not certainty and completeness time, high cost, non transparent requirements, less responsive officer often met and spread evenly in all public services today.[11]

The public service effort is synergic with welfare state followed in Indonesia. Each governmental actions in implementing public services aimed at creating welfare for the communities. Then the societal satisfaction become the measuring rod. Administrative services that is arbitrary, able to produce administrative violation. Sipayungstates that: "Each person has rights and obligation. Each citizen has rights to get good services, from government. Each person also has rights to obtain legal protection from arbitrary action from officials of state administrative officials."[12]
Relates with the implementation of local government administration that is less good based on the general principles of goo implementation can be seen from many complaints from societies about public servicesthat still not accommodated well in several areas. Below is institution with highest rank to the lowest rank viewed from the maladministration report of public servicesby societies:

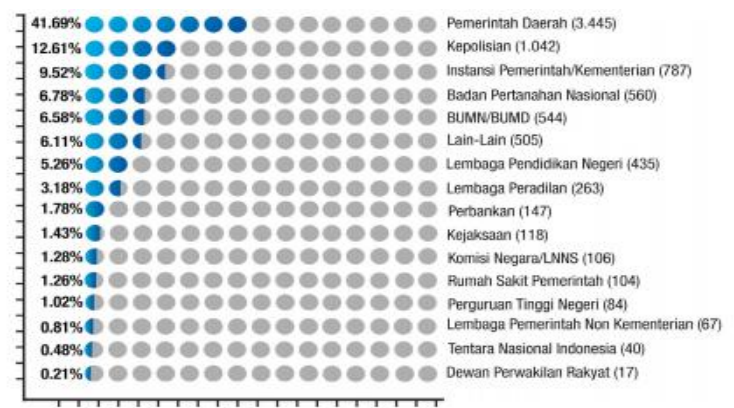

Data: Yearly Report of Ombudsman 2017 di http://www.ombuds man.go.id

Mal administration report in relation with public services, it is studied its relation with the report reason often be stated. The maladministration report bases in this graph below:

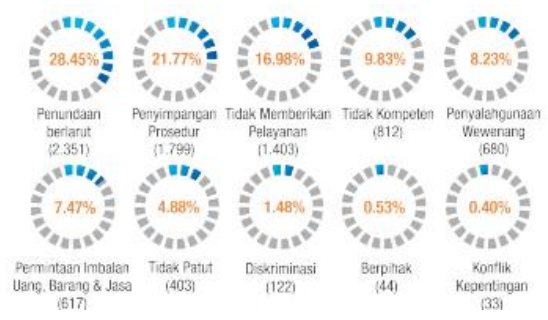

Data: Yearly Report of Ombudsman 2017 di http://www.ombuds man.go.id

From the circle graph data above, can be concluded that the highest three in the reason of maladministration is the long delay 2.351 reports $(28.45 \%)$, procedural deviance 1.799 reports $(21.77 \%)$, and don't give services of 1.403 reports $(16.98 \%)$.All of them relates with the public services implementation.

Problem relates with the many local bestuursorgaanwho conduct criminal acts or administrative violation or mal administration, become the ghost for the production of new policy that should refer to the public interest, but finally refer to personal or group interests. Relates with the matter, for each decision making or decision by local bestuurs organ should consider the law, professionalism or societal need, where the presence in the local government regime intentionally to help the central government in local area, also to create the close government with societies, including in it to understand to constituent need. Naweu Fu and Weijun $\mathrm{Wu}$ in journal entitled: "Reflection on Rationalization of Public Decisionmaking from the Perspective of the Administrative Law", stated:

"Rationalization of public decision-making is mainly considered from aspects of scientificity and 
professionalism while the democratization of public decision making is considered from the interest balance among all parties and the universality of participants. "[13]

The opinion strengthen, that public servicesbased on the higher level policy,should based on professionalism, and looking at the societal need.

\section{B. Supporting factors for criminal act of corruption and maladministration done by LocalBestuursOrgaan.}

Either relate to the criminal acts of corruption or maladministration at the local bestuurs organ, it is influenced by law enforcement. The law enforcement in this case relates with how the legal system can work in the societies.

Legal system theory from Lawrence M. Friedman, states that a legal system from the societal system, can work if three components in synergy. The three components are: legal substance, legal structure, legal culture[14].Relates with the matters, map the supporting factors for local bestuursorgaanto do the criminal act of corruption and mal administration, also can use the legal system theory to analyze it.

Legal substance in its relation with the legal structurerequire the legal substance that should be understood by local bestuurorgaan. Good law without understood and implemented well by the legal structure, in this case local bestuurorgaan, will not reach the strong law. Either criminal acts of corruption and maladministration done by local bestuurorgaanis very influenced by the lack knowledge about the corruption limitation in the Law for criminal act of corruption, and no understand about the state administrative law, also don't understand about general principle of good government (AAUPB).

SF Marbun,in this case stated that AAUPB serve as guidance for authority implementation of administrative official. With AAUPB the administrative officials able to control the authority so able to give law protection. It also relates with vrijbestuurowned by the administrative officials, then through AAUPB can be measured the use of the authority.

Then the legal cultureof structure or local bestuursorgaanshould be built in direction of nationalism understanding. The more eroded nationalism if ignored will cause the local bestuursorgaanbecome irresponsible.

According to Marvin Perry, "Nationalism is an aware bonding together of a group of persons who have similarity in language, culture, and history, marked with the together victory and suffering and bound each other in ceratin country."'[15] In this case, if the togetherness in a binding based on the language similarity, and others up to together suffering not anymore fertilized as the base for public servicesimplementation by each local bestuursorgaan, then the apprehensive about the individualism character that direct to the personal interest egoism will produce corruption and maladministration.

\section{Formulation of ideal law education for LocalBestuursOrgaan.}

Answering the apprehensiveness even the legal violation practice by localbestuursorgaanas stated above, it need law education for each local government organ. Intended education is the embodiment of human resources development that is aware to the law, obey to the law, and has spirit without ulterior motives for the state and societies.

Law education in this case also will answer the apprehensiveness of local government and the societies to the local government organs that haven't no legal academic bases. The legal understanding in the welfare statethat declares in the constitution as the legal state (Article 1 paragraph (3) Constitution 1945). With other words, the public services and governmental implementation in general, should based on law to embody the people welfare.

Law education that is formulated should be law education that combine material with technical substances. Law education can be packaged through education and training, so it is expected able to improve the legal skill.

Xuan Gao in journal entitled "Discussion on Interactive Mechanism of Law Education of Undergraduate Course and Vocational Education of Law",stated "The law skill is the indicator to reflect the level of practical ability of a person. Its formation relies on the degree of practice exercise. But it also needs theoretical basis to transform into practical ability. The formation of legal thinking and law skills is the result of interaction of theoretical knowledge and practice course."[16]The opinion support hypotheses that law education and training will increase the legal skill, not only theoretically but also practically.

Law education in this case can be implemented by higher education especially the law faculty cooperate with education and training of Local Staffing Agency (BKD) in each area, that has authority for the matters. Higher education especially the law faculty in this case able to give law education materially, and technically from the local BKD. BKD in this case has authority given by presidential decree to implement the law education and staffing management training in local area. The cooperation will show good synergy between local institution with higher education. The needed formulation, to synergize law education by higher education and technical training by BKD.

Law education by higher education is an opportunity to give answer about problems in the society often relate with the legal problems. Law No 12 Year 2012 about higher education, especially Article 58, confirmed that function and role of higher education as follow: (1) learning container for students and societies, (2) education container for the national leader candidates, (3) central for knowledge and technology development, (4) investigation center and moral strength to find the truth and (5) development center of national civilization development.

\section{Higher Education in Giving Law Education For State Civil Apparatus}

Higher education for container to form character and produce change agent, has moral obligation to give education including to the local bestuurs orgaan. 
Academics in the higher education not only has task to teach, but also to educate as one of three obligation of the higher education, that is education and teaching, with direction, giving law education for the local bestuurs orgaan.

Talking about law education, then it talks about the knowledge and understanding relates to the legal science.

Higher education has strategic position in improving the law education understanding and the nationalism planting for the local bestuursorgaanat the local area. Higher education should also able to give contribution to the societies, and through network development give law education for local bestuursorgaanis one of education. Its relationship with the law education, then the assignment in the law faculty in the higher education can take role to solve task to give law education for the local bestuursorgaan. Final goal here is to solve bureaucracy problem to embody good governance and character development, and mentality improvement for local bestuursorgaan.

The importance of law education in this case relate closely with the professionalism improvement. With law education, either judicative, legislative, or executive, including localbestuursorgaanwill run the role without violate the law.

Concept selected is caderization, that is giving education and training for some personnel in the section of education and training of the local BKD, then the next for the cadre will continue the work program of education and training for all local bestuurs organ at the local area. The caderization not only for 3-5 days as for education and training method (education and training). Caderization, with non regular lecturing with giving law subject by the lecturers from the law faculty, it is expected able to give better knowledge than education and training in the form of seminar for several days only.

Law education is directed to give legal materials of state administration as the managerial administration guidance or governmental administration, local government law as the foundation of governmental administration urgency at local area, state administration law as foundation to understand the institution, special criminal law including in its criminal law of corruption as the knowledge base for government action limit viewed from the law of criminal acts of corruption, and the law subject that support the implementation of public services (for example, in this case, the material regulation of public services, agrarian, goods and services procurement, and etc) suitable with the need of each institution. The giving of law subject, packaged with nationalism spirit. Then the education and training also be formulated with the planting of nationalism understanding.

\section{CONCLUSION}

The supporting factors for local bestuursorgaan to do the criminal act of corruption and mal administration, can use the legal system theory to analyze it. Law education that is formulated should be law education that combine material with technical substances.Law education in this case can be implemented by higher education especially the law faculty cooperate with education and training of Local Staffing
Agency (BKD) in each area, that has authority for the matters.

Law education can be packaged through education and training, so it is expected able to improve the legal skill. With law education, either judicative, legislative, or executive, including localbestuursorgaan will run the role without violate the law. Concept selected is caderization, that is giving education and training for some personnel in the section of education and training of the local BKD, then the next for the cadre will continue the work program of education and training for all local bestuurs organ at the local area.

\section{REFERENCES}

[1] KPK, “TPK based on profession/post," 2017. [Online]. Available: https://acch.kpk.go.id/id/. [Accessed: 15-Aug-2018].

[2] Syahrul, "Corruption and State Administration in Local Administration," 2017. [Online]. Available: https://news.detik.com/. [Accessed: 15-Aug-2018].

[3] E. Yuntho, "Corruption of Local Head and Political Dynasty in https://nasional.sindonews.com/, accessed on 15 February 2018, at 07.57 WIB.," 2018.

[4] A. Grabbilin, "19 Local Head determined as Suspect," 2018. [Online]. Available: https://nasional.kompas.com/ read/ 2018/07/19/07 554661/januari-juli-2018-19-kepala-daerahditetapkan-tersangka-oleh-kpk

[5] D. Halim, "KPK : Mass Corruption Case in Municipal Assembly of Malang City, Integrity Problems.”.

[6] Ombudsman, "Yearly Report of Ombudsman 2017," 2017.

[7] M. Thoha, Management of Civil Staffing In Indonesia. Jakarta: Kencana Prenada Media, 2008.

[8] A. G. Syaukani, Local Autonomy in Unitary State. Yogyakarta: Pustaka Pelajar, 2002.

[9] H. M. Busrizalti, Local Government Law. Local Autonomy and Its Implication. Yogyakarta: Total Media, 2013.

[10] H. A. W. Widjaja, Local Autonomy and Autonomous Area. Jakarta: Rajafrafindo Persada, 2004.

[11] Surjadi, Public Services Performance Development. Jakarta: Refika Aditama, 2012.

[12] P. J. J. Sipayung, Official as the defendant candidate in the State Administrative Court. Jakarta: Sri Rahayu, 1989.

[13] N. F. and W. Wu, "Reflection on Rationalization of Public Decision making from the Perspective of the Administrative Law," Int. Conf. Econ. Manag. Law Educ. (EMLE 2016), vol. 20, p. 405, 2016.

[14] L. M. Friedman, The Legal System. New York: Russel Sage Foundation, 1969.

[15] M. Perry, Peradaban Barat, Dari Revolusi Perancis Hingga Zaman Globalisasi. Bantul: Kreasi Wacana, 2013.

[16] X. Gao, "Discussion on Interactive Mechanism of Law Education of Undergraduate Course and Vocational Education of Law Advances in Economics, Business and Management Research," Adv. Econ. Bus. Manag. Res. Vol. 20, 2nd Int. Conf. Econ. Manag. Law Educ. (EMLE 2016), vol. 20, p. 156, 2016. 